\title{
Digital Marketing Transition for Luxury Industry Under the New Coronavirus Epidemic - The Case of Burberry
}

\author{
Xinhao Chen ${ }^{1, \dagger}$, Siyi Cheng ${ }^{2, *}{ }^{*}$, Ruijie Shu $^{3, \dagger}{ }^{\text {, Yang Yang }}{ }^{4, \dagger}$ \\ ${ }^{1}$ School of Economics and Management, Beijing Forestry University, Beijing 100089, China \\ ${ }^{2}$ School of Business and Management, Tamkang University, New Taipei 251301, China-Taiwan \\ ${ }^{3}$ School of Accounting, Jiangxi University Of Finance And Economics, Nanchang 330013, China \\ ${ }^{4}$ School of Economics, Finance \& Accounting, Coventry University, Coventry CV1 5FB, United Kingdom \\ *Corresponding author. Email: 408684016@gms.tku.edu.tw \\ These authors contributed equally.
}

\begin{abstract}
With the prevalence of digital marketing, the luxury industry no longer serves a small group of people as it did in the previous hundred years but is gradually moving into the lives of more ordinary people. However, the sudden epidemic has put a damper on the luxury industry's growth by limiting travel and consumption. There has not been much research on finding breakthroughs through developing digital marketing in the epidemic context. This paper aims to analyse luxury brands in the epidemic context, using quantitative and qualitative methods to determine the epidemic's impact on luxury brands and give sound recommendations. We selected Burberry Group as a sample for this study. We applied DuPont analysis and Porter's Five Forces model to analyse the financial and management data of Burberry for the last three years. Firstly, our quantitative analysis reveals that the main reason for Burberry's weaker operating position in FY19-20 compared to the previous year was the decline in both retail and wholesale revenues due to the impact of the epidemic. Secondly, from a qualitative perspective, Burberry's strategy of developing its digital marketing could be effective in helping it to open up markets as well as quickly return to its pre-epidemic revenue levels. Still, As the epidemic gradually comes under control and digital marketing continues to evolve, the total revenue will return to steady growth in 2024. The findings of this paper provide a new theoretical research context for digital marketing, namely the COVID-19, on the one hand, a practical basis for the digital transformation of companies.
\end{abstract}

Keywords: COVID-19, Luxury Industry, Financial Analysis, Business Strategy.

\section{INTRODUCTION}

The new coronavirus that swept the world at the end of 2019 has dealt a blow to society regarding health and the environment and wreaked havoc on the global economy.

Since the end of 2019, worldwide air traffic has been reduced in mobility by the travel restrictions brought about by the new coronavirus and has reduced world GDP by $0.02 \%$ to $0.12 \%$ and could even bring about an unemployment rate of $1.41-1.67 \%$ in 2020. Moreover, because the spread and control of the outbreak vary, some countries will be more affected, subjecting most European airlines to travel bans [1]. The luxury goods sector, which is closely linked to tourism on the offline retail side, has also been affected by travel restrictions. Roggeveen \& Sethuraman (2020) mention in their article that luxury goods and high-end retailers will suffer as non-essentials during the recession brought on by this epidemic [2]. Moreover, the negative impact of the sudden outbreak on the fashion industry has been enormous, with the loss of distribution channels causing sales of luxury brands to fall and forcing them to raise prices to compensate for the losses [3]. In addition to raising selling prices, luxury brands are cutting budgets in a variety of ways. In response to slumping sales during the epidemic, Burberry expects to reduce its cost burden by cutting 500 worldwide jobs, including 150 at its UK headquarters[4].

From domestic scholars, with the proliferation of Internet users and the "big explosion" of data, digital 
marketing has begun to receive attention and use in many industries. Digital marketing usually refers to the practical activities of using digital communication channels to promote products and services. It includes not only Internet communication channels but also mobile phone communications and outdoor digital advertising. The digital marketing studied in this article is mainly based on the Internet. The platform uses massive data to achieve marketing precision and quantifiable marketing effects through digital multimedia channels. It is a databased high-level marketing activity. Digital marketing has been given new life in the era of big data, and the displayed characteristics are also different from those before the advent of big data. In the era of big data, digital marketing focuses more on mining the massive data behind consumers and understanding user needs. To provide personalized and cross-platform marketing solutions[5].

From domestic scholars, as virtual survival becomes the most important way of technological survival, fundamental changes have taken place in economic development patterns and marketing methods. Digital marketing is marketing in a virtual living space. Digital marketing will be impossible without the virtual living space. The development status, presentation form, and development prospects of virtual living space are the basic prerequisites for digital marketing. The virtual existence brought about by digital technology is an important background for the emergence of digital marketing[6].

From foreign scholars, digital marketing, according to studies made in the last five years, has redefined the strategies of traditional marketing and is currently an indispensable tool for the competitiveness of the companies in a society that is governed by the movement, fluidity, and the easy access to information at any given time and place. The companies that have become aware of the importance and growth of the digital era have begun to invest a greater percentage of their budgets into the development of platforms and tools of digital communication and fully adapted content. Citation An effective digital marketing involves content and quality that have constantly adapted to the technological development of devices that distribute information and contents. Digital marketing, as well as traditional marketing, have tangible and intangible elements. On one side, the tangible elements of digital marketing correspond to technological and electronic developments on the part of the IT companies (Information technology), and intangible ones, whose development depends precisely on the investment and budget allocated by the companies for the generation of content available through a variety of virtual platforms. This has significantly impacted the behaviour of the market in the luxury sector[7].
From foreign scholars, digital marketing can be identified as a form of direct marketing that connects the buyers with the sellers electronically through interactive technologies such as emails, websites, social networks, the online forum, newsgroups, interactive television, and mobile communications, etc. According to the high level of connectivity, digital marketing facilitates many to many communications. It normally uses to promote products and services in a timely, relevant, personal and cost-effective manner. The world of fashion has emerged due to the fortification of digital marketing and branding and the innovative usage of technology embedded with the most recent fashion trends[8].

From domestic scholars, digital marketing is not a new concept. It has gradually developed from extensive manual workshops such as portal website advertising, email push, blog, and search marketing to personalized and precise marketing means, represented by social media marketing, short video marketing, and content marketing. What impresses enterprises most is that digital marketing can solve the marketing problem of "I know half of the advertising expenses are wasted, but I don't know which half is". It is what we call accurate and transparent and obtain a higher return on investment with lower cost[9].

From domestic scholars, digital word marketing is a new marketing method in recent years. Data drive it, but it is simple digital marketing and a combination of advanced technical means and innovative commercial marketing methods to accelerate marketing communication and build a new rule and order of the industry[10].

Digital marketing is transmitted through a digital network. It focuses on the effective management of logistics, capital flow, and information flow. Coordination and unity to achieve customer satisfaction and enterprise profitability[11].

From the existing studies, it can be seen that as it has only been less than two years since the initial outbreak, the existing studies do not have much specificity on the financial analysis of companies in the context of this sudden outbreak. While online sales, as a sales channel resulting from the development of the Internet ecosystem, online sales are becoming a more mainstream distribution channel in today's environment. As a top luxury brand in the UK, with its centuries of operation and colossal scale, Burberry can provide a sample for studying the survival and development of luxury brands under the epidemic.

Therefore, in this paper, Burberry is selected as the subject of the study. Its financial performance and development strategy in the financial year 2019-2020 in the epidemic context will be analysed using quantitative research methods of DuPont analysis and Porter's Five 
Forces qualitative research methods. Finally, reasonable recommendations will be given.

\section{DATA AND METHOD}

\subsection{Data}

The data cited come from the official websites of Burberry. The financial reports from 2017 to 2020 are presented in the section of investors, and we mainly use the figures of those four years to analyze the operating situations for Burberry. Those reports are published in June of each year, and we mainly use the data of income statements and the balance statements to fully discuss the financial conditions of Burberry.

Burberry was founded in 1856 and started by inventing the waterproof fabric, gabardine, which was widely used in troops for its breathability and convenience. Since then, Burberry mainly produced the trench coat, which is typical for its classical grid patterns. Nowadays, the Burberry Group is one of the eminent corporations with a high reputation in the luxury industry and is well-known for its history and brand culture behind. The company has a large customer base with a great proportion of British customers. It has extended its services and products to various aspects like cosmetics, clothes, accessories, etc. To entrench its status firmly in the fashion area and to offer high-quality services to people, grappling with all kinds of new risks coming from a new era and positively facing new challenges is necessary for the company.

\subsection{Method}

\subsubsection{The method of quantitative analysis}

To present the conditions of the profitability, the operating situations, and the solvency of Burberry, The research uses the DuPont analysis to calculate financial indicators from 2018 to 2020 based on multiple years' financial data in each financial report. DuPont analysis is an emerging analytical method in the 19th century[8], and was firstly used by DuPont company and could illustrate the correlations between financial indicators.

The equation of the DuPont analysis is :

$\mathrm{ROE}($ return on equity $)=\mathrm{ROA}($ return on assets $) *$ equity multiplier

$\mathrm{ROE}=$ net income/average equity (average equity is the mean of the sum of the total equity in the first and last day of the fiscal year)

$\mathrm{ROA}=$ net income/average assets (average assets is the mean of the sum of total assets in the first and the last day of the fiscal year)

Equity multiplier=average assets/average equity
We can use the ROE, ROA, and equity multiplier to reflect the situation of the company's profitability, operation, and solvency separately.

The factor analysis approach is a method to analyze factors individually. Given that other factors remain the same, it can analyze the contribution of one factor to the consequence. Therefore, after we calculate the indicators above, we use the factor analysis approach to analyze how ROA and equity multiplier change contribute to the change of ROE in each year. To have a comprehensive quantitative analysis, we calculate the discrepancies of the financial indicators in multiple years in both absolute meaning and relative meaning. The absolute meaning merely uses the difference between the values of the latter year and the former year to describe the changes. In contrast, the relative meaning uses the quotient between the data of the latter year and the former year to make comparisons.

\subsubsection{The method of qualitative analysis}

In qualitative analysis, we use Porter's Five Force Framework. Porter's Five Forces Framework is a method for analysing the competition of a business. It draws from industrial organization (IO) economics to derive five forces that determine the competitive intensity. The fiveforces perspective is associated with its originator, Michael E. Porter of Harvard University. This framework was first published in Harvard Business Review in 1979. Porter refers to these forces as the microenvironment to contrast it with the more general term macroenvironment. They consist of those forces close to a company that affects its ability to serve its customers and make a profit. A change in any of the forces normally requires a business unit to re-assess the marketplace, given the overall change in industry information. Porter's five forces include three forces from 'horizontal' competition - the threat of substitute products or services, the threat of established rivals, and the threat of new entrants - and two others from 'vertical' competition - the bargaining power of suppliers and the bargaining power of customers[12].

\section{RESULTS AND DISCUSSION}

To discuss the operational conditions of the luxurious industry through the example of Burberry, the research analyzes from the perspective of quantity and quality. In the part of quantitative analysis, we combine the DuPont equation and the approach of factor analysis to compare the years from 2018 to 2020 . In that case, closely presenting the three financial indexes all in one equation makes the financial analysis comprehensively consider the aspect of profitability, the operating situations, and the structure of the assets and liability. Finally, we conclude that the COVID-19 affected the operational conditions of Burberry by the sales. In addition, we discuss the luxury industry mainly using the Porter's Five Force model to indicate that Burberry needs to 
face the challenges positively from the COVID-19 and seize the opportunities for profound development. Therefore, we can have an objective view of the luxury industry and the status of Burberry. In that case, we could know what Burberry needs to do to entrench its status and further its development.

\subsection{The analysis of financial indicators}

Table 1. Financial data used to calculate Dupont equation

\begin{tabular}{lccc}
\hline & 2018 & 2019 & 2020 \\
\hline Net income & 241.2 & 352.00 & 140.4 \\
Average assets & 9272.8 & 9110.4 & 11248.8 \\
Average equity & 1561.6 & 1442.7 & 1339.4 \\
\hline
\end{tabular}

The research extracts the data from the income statements and the balance statements from 2017 to 2020 .

The researchers assume that the ROA and equity multiplier in 2018 is p0 and q0, respectively, the ROA and equity multiplier in 2019 is p1 and q1, the ROA and equity multiplier in 2020 is $\mathrm{p} 2$ and $\mathrm{q} 2$, respectively. As for the situation of the year from 2018 to 2019, the year of 2018 is the based period, and the year 2019 is the reporting period. So is the year from 2019 to 2020 .

According to the equation of DuPont analysis which is mentioned before, using the data above could calculate the factors of the DuPont equation.

Table 2. The factor of Dupont equation

\begin{tabular}{llll}
\hline & 2018 & 2019 & 2020 \\
\hline ROE & $\begin{array}{l}\mathrm{p} 0 \mathrm{q} 0=15.45 \\
\%\end{array}$ & $\mathrm{p} 1 \mathrm{q} 1=24.4$ & $\mathrm{p} 2 \mathrm{q} 2=10.48$ \\
& $\mathrm{p} 0=10.4 \%$ & $\mathrm{p} 1=15.45 \%$ & $\mathrm{p} 2=4.99 \%$ \\
$\mathrm{ROA}$ & $\mathrm{q} 0=1.48$ & $\mathrm{q} 1=1.58$ & $\mathrm{q} 2=2.1$ \\
$\begin{array}{l}\text { Equity } \\
\text { multiplier }\end{array}$ & & &
\end{tabular}

Then we use the factor analysis approach, from the perspectives of absolute meaning and relative meaning, to research the changes of indicators among three years. We suppose that p1q0-p0q0 could be seen that how much the change of ROA in the absolute meaning leads to the change of ROE from 2018 to 2019 , and $\mathrm{p} 1 / \mathrm{p} 0$ could be seen that how much the change of ROA in the relative meaning give rise to the change of ROE from 2018 to 2019. Also, p1q1-p1q0 could be seen that how much the change of equity multiplier in the absolute meaning leads to the change of ROE from 2018 to 2019 , and q1/q0 could be seen that how much the change of equity multiplier in the relative meaning give rise to the change of ROE from
2018 to 2019 . The year from 2019 to 2020 is in the same case.

1)From 2018 to 2019,

a.In the absolute meaning,

The change of ROE: p1q1-p0q0 $=8.95 \%$

The change of ROA drive p1q0-p0q0 $=7.622 \%$

The change of equity multiplier drive p1q1$\mathrm{p} 1 \mathrm{q} 0=1.545 \%$

b.In the relative meaning,

The change of ROE: p1q1/p0q0= 1.58

The change of ROA drive $\mathrm{p} 1 / \mathrm{p} 0=1.49$

The change of equity multiplier drive $\mathrm{q} 1 / \mathrm{q} 0=1.07$

Therefore, the whole increment of ROE consists of the increase of ROA, $7.622 \%$, and the increase of the equity multiplier, $1.545 \%$. Moreover, 1.49 times the original ROA and 1.07 times the original equity multiplier leads to 1.58 times the original ROE.

2)From 2019 to 2020 ,

a.In the absolute meaning,

The change of ROE: p2q2-p1q1= $-13.92 \%$

The change of ROA drive p2q1-p1q1 $=-16.53 \%$

The change of equity multiplier drive p2q2$\mathrm{p} 2 \mathrm{q} 1=2.59 \%$

b.In the relative meaning,

The change of ROE: p2q2/p1q1=0.43

The change of ROA drive $\mathrm{p} 2 / \mathrm{p} 1=0.32$

The change of equity multiplier drive $\mathrm{q} 2 / \mathrm{q} 1=1.33$

Therefore, the whole drop of ROE consists of the decrease of ROA, $-16.53 \%$, and the increase of the equity multiplier, $2.59 \%$. Moreover, 0.32 times the original ROA and 1.33 times the original equity multiplier leads to 0.42 times the original ROE.

Therefore, we can conclude that, from 2018 to 2019, the ROE increased from $15.45 \%$ to $24.4 \%$, and the ROA drove the most in the perspective of both absolute and relative meanings. Hence, the speed of turnover of assets probably became faster than the year before. The net income went up too, which means the company's efficiency of managing the assets is high and is in a promising operation situation.

However, from 2019 to 2020, the equity multiplier climbed from 1.58 to 2.1 , and the ROA dropped significantly and lowered the profitability in the reflection from the fall of ROE. Therefore, the company earned less money from the normal operating activities and also borrowed money to increase the proportion of the liability, which could improve the equity multiplier. 
From the financial report, Burberry had closed $50 \%$ of the stores in 2020 due to the COVID-19, and the income from the retail and wholesale, which are the two main ways for the company to make money, shrank dramatically. That may be considered as the most important reason for the worse operating conditions compared with 2019 for Burberry.

\subsection{Five force analysis}

We use the five forces analysis method to have qualitative analysis. And we analyze Burberry's own brand advantages and potential competitive parts. Besides, we can also see the influence of COVID-19 and how Burberry can change its strategy.

\subsubsection{Threat of new entrants}

The threat of new entrants to luxury brands is low. Firstly, this industry has an existing high barrier, luxury brands need large funds to start, and they always need a profound cultural foundation, so it's not easy to start a new luxury brand. Secondly, the old brands have the advantage of economies of scale. They can have lower prices than new brands. Finally, the old brands have the advantage of economies of scale. They can have lower prices than new brands.

\subsubsection{Bargaining power of suppliers}

The bargaining power of suppliers is high. The two main suppliers of luxury are raw materials and labor. A good product mainly depends on high-quality materials and professional designers and makers. So good raw materials and talented designers are powerful. Burberry uses high-quality raw materials. Nowadays, $75 \%$ of cotton is bought from BCI. The association is a non-profit organization that works to improve the way cotton is grown worldwide. They are trying to reduce the pressure of cotton growing on the environment. Besides, Burberry uses innovative materials in a wide range of products. The brand ECONYL collection features sustainable nylon fabrics made from recycled fishing nets, fabric waste, and industrial plastics.

\subsubsection{Bargaining power of customers}

However, the bargaining power of customers is low. For the luxury industry, the audiences are fewer than the normal bag or clothes industry. Luxury goods are not necessary things for most customers. Additionally, the switching cost in luxury is low. If customers want to switch the products from GUCCI to Burberry, they don't need to pay anything. Additionally, although pricing suggests quality $\&$ desirability high price range has made it reachable within the pocket of few customers only. The young age population which aspires to lead their lifestyle can't afford for high priced products.

\subsubsection{The threat of substitutes}

As a luxury industry, the threat of substitutes is moderate. If people want to buy luxury, they have many choices, like GUCCI, Prada, etc. They do not need to focus on only one brand. Intense competition from other players in Players like Gucci, Louis Vuitton \& Prada having presence worldwide possess a serious threat to the existence of Burberry. However, every brand has its own special and famous design and products, the customers' aesthetic is also quite fixed. So the threat of substitutes is moderate.

\subsubsection{Industry rivalry}

The industry rivalry of the luxury industry is moderate. In this industry, the diversity of competitors' approaches is quite the same. For goods, they all sell bags, clothes, perfumes, and cosmetics. However, Burberry has twice received a Royal warrant, once by Queen Elizabeth II and once by Prince Charles. The company can publicize that they are the supplier of products to the royal family. These historic accomplishments have added great value to the brand. Besides, Burberry has its own special symbol: a distinctively checked pattern. Burberry's distinctive check pattern is one of the most widely copied trademarks in the world. The brand is also well known for creating the trench coat primarily for the 1st world war, which became popular after that.

As we can see, in the luxury industry, brands don't need to worry about new entrants and the bargaining power of customers. However, they should care about the bargaining power of suppliers, threats of substitutes, and rivalry of industry. Since the COVID-19 hit the luxury industry hardly, luxury goods are unnecessary for most families, so they prefer cheaper substitutes. It has a big impact on the luxury industry. Burberry has its own brand characteristics and advantages, such as environmentally packing and transfer, good raw materials, and private imprinting service. But it still needs to consider the impact of the epidemic. Furthermore, with the development of science and technology, digital business strategy is becoming more and more popular. Under this situation, Burberry should transfer to digital marketing immediately.

\section{CONCLUSION}

The above is our analysis of the luxury industry under the COVID-19.

From our perspective, now because of COVID-19, at present with $50 \%$ of stores closed and uncertainty in the global economic context which is giving rise to a wide range of external market forecasts, all of which are projecting a significant fall in the luxury market. Besides, now there is a large number of goods reduced in price, I 
forecast this situation will remain one to two years, until 2023 , the price will increase and return to normal level or even become higher.

So to forecast the revenue in the future, we follow the segments divide by Burberry. They divide their revenue into retail, wholesale, and license. For retail, it was affected by external elements mostly. From 2019 to 2020, the retail revenue has decreased because of COVID-19, so we forecast that 2021 and 2022 will be the bottom of revenue. But since 2023, because the situation of COVID-19 is improving and the new vaccines are widely available, the retail will increase and return to a normal level. And the revenue of retail will be going up around $5 \%$ every year. The revenue change of wholesale is similar to retail. However, the COVID-19 does not affect wholesale so much. So the increase rate almost remains $1 \%$, and the revenue continues to rise. In addition, we predict 2022. The revenue will exceed 2019. We think that the revenue of the license will stay the same because the license is not affected by the price change and volume, so it will rise steadily at about $3 \%$ a year until 2024. The revenue maybe reaches 54.07 million.

Overall, we forecast that the total revenue will decrease to 2544 in two or three years. It will increase because of the economic improvement, and until 2024 the amount of money start to exceed 2020 and finally reach 2857.64 million. Additionally, COVID-19 did not influence the strategy of Burberry. Now their strategy is still a differentiation strategy. Launched in November 2017, our strategic focus on firmly rooting Burberry in luxury fashion. Although their products are very expensive, they are high quality, and they have unique brand features. So they prefer customers to pay a high price for their products.

However, now with the influence of COVID-19, lots of offline shops closed. And the epidemic made it people inconvenient to shop in offline stores. Meanwhile, now under the digital age, Burberry needs to change its strategy immediately. They should focus on digital marketing strategy.

This strategy has lots of advantages. First, digital marketing strategy is low-cost. Most processes can be finished online. It can help Burberry to reduce lots of labor costs and transport costs. For Burberry, they need to do are expand and improve their online service. For example, they can hire some professional designers to design the website and hire some online staff. Second, digital marketing can provide customers personalized service. Expect offline big screens, Burberry can put more attention on digital marketing. They can improve their search engine ads and have interactive services. According to customers' needs, they can also track each customer's sales habits and hobbies. Third, digital marketing is creative and flexible. It won't be influenced by the limited of goods shelf and stock. And it can also provide customers bigger platform and make them have a bigger choice space. So Burberry needs to analyze all kinds of background data, like sales amount, inventory amount, website views amount, and so on.

This paper examines the survival and development of the luxury goods industry, which struggles in the face of the epidemic, through a study of Burberry, using a combination of quantitative and qualitative analysis.

In terms of theory, due to the rarity and suddenness of large-scale global epidemics, the analyses of luxury brands in the context of COVID-19 introduced a new perspective on the luxury industry in terms of strategic analysis.

In practical terms, as a stalwart in the luxury industry, the financial and strategic analysis using it as a sample in this paper can also provide an idea for other luxury brands to develop.

\section{REFERENCES}

[1] IACUS S, NATALE F, SANTAMARIA C et al., . Estimating and projecting air passenger traffic during the COVID-19 coronavirus outbreak and its socio-economic impact[J]. Safety Science, 2020, 129: 2-9.

[2] ROGGEVEEN A, SETHURAMAN R, . How the COVID-19 Pandemic May Change the World of Retailing[J]. Journal of Retailing, 2020, 96(2): 169171.

[3] PEIYU W, . Analysis on the Different Response of Fast Fashion Brands and Luxury Brands to the Epidemic[J]. Proceedings of the 2020 2nd International Conference on Economic Management and Cultural Industry (ICEMCl 2020), 2020 .

[4] Burberry to cut 500 jobs worldwide in $£ 55 \mathrm{~m}$ costsaving drive[EB/OL]. the Guardian, 2021. (2021)[2 $021-05-$

21]. https://www.theguardian.com/fashion/2020/jul /15/burberry-to-cut-500-jobs-worldwide-in-55mcost-cutting-drive-covid-19.

[5] Tan Xiaoxi. Research on the Digital Marketing Strategy of Luxury Clothing Brands Based on Big Data [D]. Beijing Institute of Fashion Technology, 2015

[6] Yao Xi, Qin Xuebing. Technology and survival: the essence of digital marketing $[\mathrm{J}]$. Journalism University, 2013(06): 58-63.

[7] Rios A E. The Impact of the Digital Revolution in the Development of Market and Communication Strategies for the Luxury Sector (Fashion 
Luxury)[J]. Central European Business Review, 2016, 5(2):17-36.

[8] Rathnayaka U. Role of digital marketing in retail fashion industry: A synthesis of the theory and the practice $[\mathrm{J}]$. Journal of Accounting \& Marketing, 2018, 7(02).

[9] Yang M F . Application Research of DuPont Analysis Method in Enterprise Profit Model Analysis[J]. Value Engineering, 2019.

[10] Li Xiaoxue. Challenges and developments in digital marketing in the era of Internet plus. [J]. modern marketing (School Edition), 2021 (05): 50-51.

[11] Liu Xiaoran. Research on the status quo of traffic star endorsement in the era of digital marketing [J]. China Press, 2021 (08): 58-59

[12] Shen Tao, Mao Chunmei. Dynamic mechanism construction of digital marketing industry -- Based on the perspective of audience, content and intelligent media selection [J]. Journal of Social Sciences of Harbin Normal University, 2019, v.10; No.55(06):105-110. 